Western University

Scholarship@Western

Law Publications

Law School

2002

\title{
Remedies and Conformity under the WTO Agreement
}

Chios Carmody

The University of Western Ontario

Follow this and additional works at: https://ir.lib.uwo.ca/lawpub

Part of the International Trade Law Commons

Citation of this paper:

Carmody, Chi. 2002. "Remedies and Conformity Under the WTO Agreement." Journal of International Economic Law 5 (2): 307-329. doi:10.1093/jiel/5.2.307. http://resolver.scholarsportal.info/resolve/13693034/v05i0002/307_racutwa. 


\title{
Remedies and Conformity under the WTO Agreement
}

\author{
by Chi Carmody*
}

I. Introduction

II. Remedies in Public and Private Law

III. Remedies in International Law

IV. $\quad$ Remedies under the WTO Agreement

V. WTO Remedies and the Context of Conformity

VI. Conclusion

\section{Introduction}

The recourse available for breach of a legal duty is of central interest in international law today. Ubi jus, ibi remedium goes the Latin maxim ("where there is law, there is a remedy"), a phrase that suggests a close correspondence between laws and remedies - and a certain deficiency where there is not. At a time of general rededication to international law, increased reference to its remedies is therefore not surprising. ${ }^{1}$ This is particularly true for the remedies of the World Trade Organization (WTO), an entity whose creation has been celebrated principally because of its binding quality. ${ }^{2}$ Perhaps more than any other aspect of its operation, WTO dispute settlement's obligatory character and the duty to comply compel our attention because they appear to do what for so long has been elusive in international law: they enforce.

Under the WTO's predecessor, the General Agreement on Tariffs and Trade ${ }^{3}$ (GATT), a single country could block the formation of a panel of trade experts to hear a dispute, it could block adoption of the panel's final conclusions, and it could refuse to implement. Occasionally,

\footnotetext{
* Assistant Professor, Faculty of Law, University of Western Ontario, London, Ontario, Canada. The writer can be contacted at ccarmody@uwo.ca. The writer like to thank Amy Jacob for her assistance in creating tabular material for this article.

${ }^{1}$ For some recent work, see generally Malcolm D. Evans (ed.), REMEDIES IN INTERNATIONAL LAW (1998); Dinah Shelton, REMEDIES IN INTERNATIONAL HUMAN RIGHTS LAW (1999).

2 Robert E. Hudec, The New WTO Dispute Settlement Procedure: An Overview of the First Three Years, 8 MinN. J. GLOBAL TRADE 1, 2 (1999) (commenting that "The creation of the new WTO dispute settlement procedure was viewed as a signal event in international legal affairs - the birth of an important new legal institution that seemed to have unusually effective powers to regulate an important area of government economic policy"); Jay L. Eizenstat, The Impact of the World Trade Organization on Unilateral United States Trade Sanctions under Section 301 of the Trade Act of 1974: A Case Study of the Japanese Auto Dispute and the Fuji-Kodak Dispute, 11 EMORY INT'L L. REV. 137 (1997) (referring to the fact that the Uruguay Round "has created the WTO, a world trade body that will infuse the GATT system with comprehensive, effective, and enforceable world trade rules and procedures.").
}

${ }^{3} 55$ U.N.T.S. 194, T.I.A.S. 1700 (Oct. 30, 1947). 
each of these things happened. ${ }^{4}$

Today, however, the situation is very different. With minimal delay a WTO member country can now bring other members before panels to determine whether their national measures are WTO-consistent. If not, the usual remedy is for the panel to recommend that the offending measure be brought "into conformity" with the organization's basic treaty, the WTO Agreement. ${ }^{5}$ The preferred outcome of WTO dispute resolution is a settlement between the parties consistent with the treaty, ${ }^{6}$ but if none can be achieved then conformity normally involves amendment or withdrawal of the impugned measure. ${ }^{7}$ Where conformity is not possible, the parties to the dispute can negotiate voluntary compensation, normally in the form of trade concessions so that the injured party has greater access to the offender's market. ${ }^{8}$ If all else fails, the WTO can automatically authorize the injured party to retaliate by suspending concessions. ${ }^{9}$

The outcome of this new streamlined system of dispute settlement has been remarkable. Since the WTO's creation in January 1995 some 242 disputes have been initiated in 180 distinct cases, but only 4 cases have resulted in the suspension of trade concessions, and only one case of retaliatory suspension continues at the time of writing. ${ }^{10}$ This is several times the number of disputes litigated under GATT and tentatively suggests that WTO dispute settlement is perceived by its member countries to preserve and enhance the integrity of the world trading system.

Despite such success, WTO dispute settlement has many detractors and raises profound

${ }^{4}$ For a full discussion of these defects of the original GATT see Michael Patrick Tkacik, PostUruguay Round GATT/WTO Dispute Settlement: Substance, Strengths, Weaknesses and Causes for Concern, 9 INT'L LEGAL PERSPECTIVES 169 (Fall 1997).

533 I.L.M. 1125 (1994).

${ }^{6}$ As provided for by Art. 3.7 of the WTO Dispute Settlement Understanding, 33 I.L.M. 1125 (1994), the WTO's code of dispute settlement procedures.

7 lbid. DSU Art. 3.7 provides that "In the absence of a mutually agreed solution, the first objective of the dispute settlement mechanism is usually to secure the withdrawal of the measure concerned ....".

$8 \mathrm{lbid}$. Compensation is to be granted on an MFN basis as required by the phrase "consistent with the covered agreements" appearing in DSU Art. 22.1.

9 "The last resort which this Understanding provides to the Member invoking the dispute settlement procedures is the possibility of suspending the application of concessions or other obligations under the covered agreements on a discriminatory basis ...": ibid.

10 Statistics taken from the WTO website, visited Feb. 2, 2002. Suspensory retaliation continues in fact in EC-Measures Concerning Meat and Meat Products (Hormones), WT/DS26-48. In that case authorization for the United States and Canada to retaliate in the total amount of $\$ 124$ million was granted in July 1999. 
questions about the nature of the remedies available. Quite apart from the issue of whether it is the process of the dispute settlement or the imposition of specific countermeasures that make countries comply, one can legitimately wonder where the insistence on conformity comes from? In an era when so much of law, including international law, has become preoccupied with corrective justice - that is, the quantification of injury, the compensation of the plaintiff, and the punishment and deterrence of wrongdoers - how does a panel's bare recommendation to bring measures "into conformity" offer any hope of justice at all?

The unknown in each of these questions points to an urgent need to identify basic remedial principles and to link them with what the WTO Agreement now provides. We have to understand how the WTO's conformity requirement fits into the broader matrix of remedies in domestic and international law, and to appreciate the context of WTO compliance. Only then do the logic and limits of WTO remediation become clear.

This task is essential because WTO remedies are perceived to be - as the maxim at the outset of this article indicates - at the very core of the WTO legal system and because they are increasingly greeted with skepticism, both by those who equate the WTO with the uneven project of globalization and by commentators who see them as flawed. In the past year several writers have suggested that more coercive options are necessary. ${ }^{11}$ Others have suggested modifications to the implementation process, for instance, by getting "under the skin" of the state and promoting compliance through appeals to trade-liberalizing interests, or by "tweaking" existing procedures. ${ }^{12}$ Still others have advocated abandoning WTO dispute settlement altogether, at least for certain types of disputes. ${ }^{13}$

This article posits that such suggestions are misplaced. First, the corrective aim of WTO remedies is not to compensate the victim, but rather to induce the wrongdoer to comply. This

\footnotetext{
11 Joost Pauwelyn, Enforcement and Countermeasures in the WTO: Rules are Rules - Toward a More Collective Approach, 94 A.J.I.L. 335 (2000).

12 Steve Charnovitz, Rethinking WTO Trade Sanctions, 95 AM. J. INT'L L. 792 (2001); Edwini Kessie, Enhancing Security and Predictability for Private Business Operators under the Dispute Settlement System of the WTO, J. WORLD TRADE 1 (Dec. 2000); Patricio Grané, Remedies under WTO Law, 4:4 J. INT'L ECON. L. 755 (2001).

${ }^{13}$ E.U., U.S. Take Sharply Different Tacks on Dispute Resolution, INSIDE U.S. TRADE (June 22, 2001) (discussing a U.S. proposal to the EC for a mediation track for transatlantic trade disputes outside the framework of the WTO Agreement).
} 
realization counters the notion that somehow an injustice is being perpetrated under the existing system. Simply put, it was not designed to compensate. Second, the varied and textured nature of obligations under the WTO Agreement means that there can be no "one-size-fits-all" approach either to remedies or to conformity. The case law to date suggests that remedies are only part of the conformity story. Depending upon an obligation's specific character, it will leave a varying amount of room for sovereignty and for a reconciliation of interests to take place that may well be independent of the remedies available. Instead, there is a need to appreciate WTO remedies in context and for the considerable achievement they already represent. Thus conceived, WTO remedies have done a reasonable job of providing security and predictability to individual traders and countries alike. Marginally more conformity may come from greater remedial precision, but this will require negotiation and a willingness to live and trade by global rules.

\section{Remedies in Public and Private Law}

WTO remedies — that is, settlement, withdrawal, compensation, or retaliatory suspension referred to above — are fundamentally remedies of public law, that is, the law of government in relation to its parts or in relation to individuals. Public law is above all concerned with the exercise of government power. In this highly discretionary milieu, the traditional remedies of private law, specific performance or a corrective measure of damages, were not always appropriate.

For one, specific performance runs contrary to the sovereign power of a government to govern. The traditional thinking was that a government could not be compelled to do anything. For another, damages assume a contractual matrix about the task of government that was often missing. The idea of social contractual ordering has been around since the time of Rousseau, and we often speak loosely of a constitution or a polity as "a social contract", yet it is difficult to give tangible evidence of what this arrangement entails. Most constitutional commentators would identify, at the core, some key human rights — of speech, assembly, and belief, for instance and the reasonable means for making them effective. Beyond this, however, the identification and quantification of public rights and responsibilities is elusive.

The foregoing developments have tended to promote the view of public law remedies as 
involving distributive, as opposed to corrective, justice. Corrective justice is largely about correcting the plaintiff's injury or punishing the wrongdoer's behaviour. It is specific and usually retrospective. Distributive justice, on the other hand, "leaves open what the criterion of distribution of the benefit or burden is, whether on the basis of equality, or merit, or need, or class, or height. Thus, [it] requires a political decision to fix the criterion of the distribution." 14 In distributive remediation:

[r]elief is not conceived as compensation for past wrong in a form logically derived from the substantive liability and confined in its impact to the immediate parties; instead it is forward looking, fashioned ad hoc on flexible and broadly remedial lines, often having important consequences for many persons including absentees. ${ }^{15}$

The preference for distributive justice reflects various tribunals' awareness of the limits of their role and jurisdiction. It also demonstrates an appreciation of the systemic nature of many problems that governments must deal with, of the essential lack of definition in many social and regulatory phenomena, and of the consequent impossibility of correcting all injuries that have occurred. Indeed, insistence on full repair would seem foolish, formalistic, and at odds with the tacit understanding that any deficiency goes to constructing the "new situation" 16 of the greater common good.

Remedies in public law have therefore tended to be vague and prospective, with considerable attention paid to broader societal interests. At times courts and tribunals have been tempted to become involved in the remedial enterprise through injunctions, these being defined as "a court order for a party to do, or refrain from doing, something." ${ }^{17}$ In the United States Edwin Borchard made clear popular dissatisfaction with compensatory ideals in the regulatory realm and promoted use of the declaration, or a pronouncement of the court which "authoritatively resolves disputes about the parties' [legal] rights but do[es] not end in a direct order to the defendant." ${ }^{18} \mathrm{~A}$ declaration can be employed where clarification of legal rights and duties is required and where

\footnotetext{
${ }^{14}$ K. Kress, Formalism, Corrective Justice and Tort Law, 77 lowA L. Rev. i, ii (1992).

15 Abraham Chayes, The Role of the Judge in Public Law Litigation, 89 HARV. L. REV. 1281, 1302 (1976).

${ }^{16}$ Lon Fuller \& R. Purdue, The Reliance Interest in Contract Damages, 46 YALE L.J. 52 (1936).

17 DAVID LAYCOCK, MOdeRn AMERICAN REMEdIES 2 (1985).

18 Ibid., at 3.
} 
parties are interested in preserving their relationship despite litigation. Borchard described the conciliatory value of a declaration as follows:

Not the least of the advantages of the action for a judicial declaration of rights over coercive forms of procedure is the possibility of adjudicating disputes on issues of law in simple, civilized fashion without violence or breach of economic or social relations. Legal positions can be effectively asserted, yet without that cocksure that makes defeat humiliating. Honest doubt may be admitted without sacrifice of position, where certainty is often a pretense and the setting histrionic. ${ }^{19}$

Borchard also observed that a declaration had added value in that it could promote certainty, even in the absence of a legal breach:

... the declaratory action, in extending the opportunity for [interpretative] judgments to all legal relations, inaugurated not startling novelty, but merely recognized that individual and social peace are promoted by removing clouds from legal relations whenever, by attack, challenge, or denial, they are placed in doubt and uncertainty. The action implies a recognition of the fact that the social equilibrium is disturbed not merely by an overt violation of private rights, but by a challenge which places them in doubt and uncertainty. ${ }^{20}$

Of similar use in public law remedies is "strategic ambiguity", that is, situations where the court's purposive lack of clarity is useful in overcoming present uncertainty and bringing parties to the negotiating table. ${ }^{21}$ Ambiguity can force the parties to debate the meaning of a judicial pronouncement which has narrowed, but not altogether resolved, a dispute. The parties will be compelled to further negotiate, with the prospect that the court may impose a remedy where they fail. At the same time, strategic ambiguity allows parties to deliberate, safe in the knowledge that outside interference in the dispute will be kept to a minimum. ${ }^{22}$

The foregoing observations confirm that where public law disputes arise, the decisionmaker's job is more often one of legal interpretation than of material remediation. Courts and tribunals are inhibited from exercising supervisory jurisdiction over the resolution of systemic issues by concern about the separation of powers, the need to husband scarce judicial resources,

19 EdWIn BORCHARD, DECLARATORY JUdGMENTS xv-xvi (2 ${ }^{\text {nd }}$ ed.) (1941).

20 Id., xiv.

${ }^{21}$ Cass R. Sunstein, Foreward: Leaving Things Undecided, 110 HARV. L. REV. 4 (1996).

22 Nor is ambiguity useful only to the parties involved in the dispute. It can also assist judges. Ambiguity obscures where judges are reluctant to intrude because of knowledge that involvement consumes judicial time and may compromise objectivity. In addition, where judges must become involved, their powers are necessarily engaged. Vagueness helps them to finesse the finer points of their jurisdiction and preserve the court's prestige. 
and the desire to protect their institutional reputation. This is not to suggest that judges will never issue corrective orders, but they have to be reasonably certain that their actions will be effective when they do so.

Another point that needs to be made is with respect to the correction that will be achieved. The classic private law conception of correction was plaintiff-oriented. It is the plaintiff that most evidently suffers a loss and so it is the plaintiff that should be compensated by any remedy. In public law, however, the uncertainty of the injury and the broader frame of reference often makes it more expedient to turn attention to correcting the wrongdoer, in particular, inducing them to change their behaviour. This is the focus of much administrative and criminal law today. The "turn of gaze" has had important consequences for the form of remedies in international law. III. Remedies in International Law

Remedies are problematic in international law for all of the same reasons that they are problematic in domestic public law, except that in international law concerns about sovereignty are generally even more acute. Remedies for an international wrong are something a self-serving sovereign would rarely grant. Christine Gray observes, for instance, that "there are no uniform rules governing reparations [in international law]" and adds that "[t]he determination of the consequences of a breach of international law is left initially to the discretion of the injured state."23

In more recent years, however, a second school of thinking has arisen about the obligation to remedy in international law. For instance, the Permanent Court of International Justice made clear in the Chorzów Factory case of 1927 that "It is a principle of international law that the breach of an engagement involves an obligation to make reparation in an adequate form." 24 The dispute there involved the expropriation of a German-owned match factory by the Polish government and so featured the precision and unity necessary for correction that is often missing in public law cases. Nevertheless, Chórzow Factory has proven to be an influential authority over time and is quoted extensively. Since Chórzow Factory, the requirement to correct

\footnotetext{
${ }^{23}$ Christine Gray, Judicial Remedies IN INTERnational LaW 5 (1990).

${ }^{24}$ Case concerning the Factory at Chorzów, PCIJ Series A, No. 9 (1927).
} 
has been elaborated upon by writers in international law and by the International Law Commission in its work on the Draft Articles on State Responsibility (DASR), the most recent version of which appeared in August 2001. ${ }^{25}$

The DASR presumes responsibility and sets out two basic legal consequences of an internationally wrongful act: cessation and reparation. These are defined as follows:

\section{Cessation and non-repetition}

The State responsible for the internationally wrongful act is under an obligation:

(a) To cease that act, if it is continuing;

(b) To offer appropriate assurances and guarantees of non-repetition, if circumstances so require.

\section{Reparation}

1. The responsible State is under an obligation to make full reparation for the injury caused by the internationally wrongful act.

2. Injury includes any damage, whether material or moral, caused by the internationally wrongful act of a State.

The obligation to repair is further divided into restitution, compensation, and satisfaction, each with a gradually greater substitutive character. The entire ensemble of obligations can be represented as follows:

Remedies under the Draft Articles on State Responsibility

\begin{tabular}{|c|c|c|}
\hline Obligation & Component & Description and Example \\
\hline \multirow[t]{2}{*}{ Cessation } & Cessation & $\begin{array}{l}\text { Ending illegal behaviour } \\
\text { Ex: }\end{array}$ \\
\hline & $\begin{array}{l}\text { Assurances and } \\
\text { Guarantees of Non- } \\
\text { repetition }\end{array}$ & $\begin{array}{l}\text { promise of non-repetition } \\
\text { Ex: French demand in } 1919 \text { for abrogation of Art. } 61(2) \\
\text { of the Weimar Constitution which, France claimed, } \\
\text { violated the Versailles Treaty by providing for the } \\
\text { participation of Austrian delegates in the German } \\
\text { Reichsrat (the Weimar Parliament). Following France's } \\
\text { protest, the provision was annulled by Germany. }\end{array}$ \\
\hline Reparation & Restitution & $\begin{array}{l}\text { Return of the same good or goods of the same kind } \\
\text { Ex: Return of an ancient temple through border } \\
\text { adjustment and return of archeologic objects taken } \\
\text { from it: see The Temple of Preah Vihear }\end{array}$ \\
\hline
\end{tabular}




\begin{tabular}{|l|l|l|}
\hline & Compensation & $\begin{array}{l}\text { Provision of payment to substitute } \\
\text { Ex: }\end{array}$ \\
\cline { 2 - 3 } & Satisfaction & $\begin{array}{l}\text { Expressions of regret to moral ("intangible") damage } \\
\text { Ex: }\end{array}$ \\
\hline
\end{tabular}

The DASR's practical distinction between cessation and reparation mirrors the legal distinction made between the primary obligation of halting the illegal breach and the secondary one of repairing its consequences. Why the difference? A previous Rapporteur on State Responsibility has observed that cessation assumes greater importance in international, as opposed to domestic, law because international law lacks a coercive mechanism. ${ }^{26}$ Where states cannot be compelled to take positive measures, they should at least be obliged to observe the bare rule of law. Cessation therefore stresses "not only the interest of the injured State or States but also the interests of the international community in the preservation of, and reliance upon, the rule of law."27

Reparation, on the other hand, deals with the consequences of injury and, to this extent, is seen to protect a secondary, and in some senses, a lesser, right in international law. Several distinctions between cessation and reparation require examination. First, as the Draft Articles' make clear, cessation and reparation are distinct and address different interests. Cessation targets "the wrongful conduct per se, irrespective of its consequences." That sets cessation apart from consequent injury and is an important factor in coming to the conclusion, as can now happen under the WTO Agreement, that cessation may be requested without any demonstration of injury. The remedy is a purely legal one. Second, the obligation of cessation is absolute, whereas the obligation to repair is, as seen, more evidently conditioned. Classically, the right to seek reparation belongs to the injured state alone, which must decide whether to pursue or forego it. ${ }^{28}$ Third, cessation is prospective. It means to cease the illegal activity henceforth into the future. Reparation, on the other hand, is normally retrospective, being focused on injury that has already taken place. In temporal perspective, then, cessation and reparation converge to occupy 
the entire temporal spectrum in a concurrent fashion.

What is the aim of the DASR's remedial scheme? It is evidently legal and material repair of the injured party. What about the wrongdoer? The answer to this question under the DASR is left to the separate regime of "countermeasures". These are set out in DASR Arts. 49-54 and are purely for the purpose of inducing a country to comply with its legal obligations. The aim of countermeasures, then, is purely legal, not material. The DASR Commentary explains the distinction as follows:

[countermeasures are measures], which would otherwise be contrary to the international obligations of an injured State vis-à-vis the responsible State. They were not taken by the former in response to an internationally wrongful act by the latter in order to procure cessation and reparation. Countermeasures are a feature of a decentralized system by which injured States may seek to vindicate their rights and to restore the legal relationship with the responsible State which has been ruptured by the internationally wrongful act. ${ }^{29}$

Where confusion sometimes arises from the separate regimes for correction and countermeasures in international law is that a single set of remedies has both a reparative and an afflictive character. ${ }^{30}$ Payment of compensation can, for instance, palliate the plaintiff's injuries, but it can also convince the defendant not to undertake the same wrongful act in future. This double aspect of compensation and deterrence has important ramifications for thinking about remedies under the WTO Agreement.

\section{Remedies under the WTO Agreement}

The peculiar form and function of remedies under GATT and the WTO Agreement can be attributed to the legal nature of the regime these agreements created. They are more evidently concerned with inducing compliance than with repairing the injured party's harm. Remedies under the WTO Agreement remain the familiar ones of settlement, withdrawal, compensation, and suspensory retaliation, but they are reinforced by an enhanced system of implementation.

The limits of panels' and the Appellate Body's remedial power is now set out in Art. 19 of the WTO Dispute Settlement Understanding ${ }^{31}$, which provides:

1. Where a panel or the Appellate Body conclude that a measure is inconsistent

\footnotetext{
${ }^{29}$ DASR p. 324.

30

31
} 
with a covered agreement, it shall recommend that the Member concerned bring the measure into conformity with that agreement. In addition to its recommendations, the panel or Appellate Body may suggest ways in which the Member concerned could implement the recommendations.

2. In accordance with paragraph 2 of Article 3 , in their findings and recommendations, the panel and Appellate Body cannot add to or diminish the rights and obligations provided in the covered agreements.

Article 19's mandatory language indicates that the principal remedy remains the one of "bringing into conformity". Article 19 is distinct from past practice, however, in its apparent insistence on conformity. With few exceptions, the recommendations must now recommend conformity when a violation is found, although the use of the plural "recommendations" in both Arts. 19.1-19.2 suggests that a panel might make more than one recommendation. ${ }^{32}$

The typical form of remedy under DSU Art. 19 remains a recommendation of conformity. In this connection it is useful to note that the verb "to recommend" is less coercive than "to order" or "to require", but more compulsive than "to suggest", "to note", or "to observe". It is an indicative term capable of bearing several meanings and therefore of generating consensus as each party attaches its own gloss to actions taken pursuant to it. Several international organizations have the power to make recommendations. ${ }^{33}$ The word "conform" is also ambiguous. It means to align or make consistent with, but it does not invariably mean identity with the object being conformed to. Some deviation is hinted at. In the context of the WTO a "recommendation of conformity" would appear to prohibit the re-institution of an offending measure. It does not appear to forbid measures of equivalent effect, provided they are implemented in a WTO-consistent manner. In all these senses a "recommendation of conformity" is an example of strategic ambiguity at work.

The explanation for such curious formalism lies in the fact that GATT was, and the WTO remains, principally a legal system concerned with inducing the wrongdoer's compliance as opposed to correction of the plaintiff's injury. In GATT dispute settlement a kind of estrangement took place between the parties and the concrete conflict (Entfremdung), with the material facts themselves being transformed into an abstract and artificial legal case (Rechtsstreit). The realworld impact of measures or of remedies was of little consequence. With some modification, this 
continues under the WTO Agreement.

A good illustration of GATT's legalism was United States - Taxes on Petroleum and Certain Imported Substances (Superfund) ${ }^{34}$, a case involving a tax differential on petroleum products refined in the United States. The tax was imposed by the U.S. government to help pay for various domestic environmental clean-up programs, know collectively as "Superfund". The tax was found to be GATT-inconsistent because it imposed a higher margin of tax on foreign than on domestic products. In response to the European Community's insistence that the panel require the United States to withdraw the tax differential, the panel refused, explaining that the United States had three remedial options and that it was not the role of the panel to dictate any one. The United States could eliminate the difference by lowering the tax on foreign-refined crude or raising the tax on domestic crude, or it could harmonize the rate applicable to both at some third point. Each of these options had different trade effects, but it was not the task of a panel to dictate which option the United States should implement.

Strange as the Superfund panel's conclusion may seem given GATT's objective of lowering trade barriers, the reluctance of panels to go beyond what amounted to declarative relief became an important part of GATT institutional legitimacy. The separation of legal injury from its material effects reinforced the legal nature of the regime and assured that GATT remained above the fray in any dispute over implementation. Conclusions of a similar nature have been arrived at in several WTO cases. ${ }^{35}$

Broadly speaking, the remedial experience of the WTO has been not unlike that of GATT. Several commentators note that the actual numbers of disputes, or the "throughput" of the system, has increased, but any purely quantitative measure of compliance is an inaccurate indicator of whether the substantive obligations have actually improved. The view taken here is that there remains a considerable amount of evasive behaviour "beneath the surface" of facial compliance. Countries may remove barriers, but they are not infrequently prone to replacing them with WTO-consistent measures that meet the letter, but not the trade-promoting spirit, of the WTO

\footnotetext{
${ }^{34}$ B.I.S.D. 34 ${ }^{\text {th }}$ Supp. 136 (June 17, 1987).
} 
Agreement, or that fall into grey areas where unfair trade practices persist. ${ }^{36}$

The most common remedy is a recommendation of conformity, although panels have been somewhat more careful under the WTO Agreement than they were under GATT in mentioning the exact law or regulation at issue. There have, additionally, been some cases where panels have simply made ruling or reached other conclusions. The expressed goal of WTO dispute settlement remains a settlement consistent with the applicable agreements, but the fact that the system is supposed to provide "security and predictability to the multilateral trading system" has given dispute settlement a more significant compliance aspect than in the past. Most noteworthy, perhaps, is the fact that settlements are not always made publicly accessible and tracking the actual progress of compliance remains difficult for the public. Importantly, the WTO has not taken any steps to make this information readily accessible, something that would facilitate at least the public perception of compliance. An official list, compiled and made available by the WTO Secretariat, would be helpful. A partial list of outcomes tracked for cases that have made their way to the Appellate Body is contained at the end of this article.

If settlement is not possible, withdrawal of the impugned measure is preferred. Thus, in United States - Taxes on Conventional and Reformulated Gasoline ${ }^{37}$ the United States withdrew legislation found to treat foreign-refined gasoline less favourably than American-refined gasoline and, after a process of consultation with stakeholders, replaced it with a consistent measure. There was no interval of unregulated entry since the United States replaced the inconsistent measure with a consistent one immediately at the end of the reasonable period for compliance. The norm to be complied with was the bright-line one of "no less favourable treatment", which the U.S. took to mean approximately equal treatment, and the case was resolved. There are also a number of instances where the Appellate Body has made clear that it is the application of a measure, rather than its substance, that is WTO-inconsistent. In United States - Import Prohibition of Certain Shrimp and Shrimp Products ${ }^{38}$, for instance, the Appellate Body identified application of s. 609 of the U.S. Endangered Species Act as the violation, suggesting that an 
application which did not feature these elements might leave the statute intact. The United States did change these features and, after negotiating with its trading partners, a new compliant methodology was introduced, although not without objection. ${ }^{39}$

Where settlement or withdrawal cannot be accomplished, an option is compensation. Some commentators have question whether compensation is in the nature of a simple alternative to settlement or withdrawal, but the prevailing view rightly appears to be that it is not. ${ }^{40}$ The conclusion is consistent with the compliance rationale behind WTO remedies. Traditionally, compensation has been conceived of as an adjustment of trade concessions by the wrongdoer in order to offset its wrongdoing, but in December 2001 the U.S. agreed to pay the EC \$3 million in compensation in the context of settling U.S. - Section 110(5) of the U.S. Copyright Act ${ }^{41}$, a move that could presage further use of the payment option and possibly disadvantage poor countries.

A "last resort" in remediation is retaliatory suspension, formally invoked only once under GATT and now having been requested six times in four separate matters under the WTO Agreement, is clearly the focus of greatest public attention. The DSB authorized retaliation in the sums of $\$ 191.4$ million and $\$ 201.6$ million for two plaintiffs in Bananas $I /{ }^{12}, \$ 116.8$ million and $\$ 7.6$ million for two plaintiffs in the Hormones case, $\$ 4.5$ million in Australia - Salmon ${ }^{43}$, and $\$ 344$ million in Brazil - Aircraft ${ }^{44}$. Only in the first two cases was retaliatory suspension actually invoked, and only in one does it continue in early 2002. The fact that countries authorized to retaliate have not done so suggests that there is abiding concern about the efficacy of suspension since it is the injured country which effectively "injures itself again" by having to close its market to selected foreign goods. Nevertheless, the fact that post-adjudicative settlements have been reached in two of the four matters indicates that sanctions have some real value. If they are not effective as a deterrent, they may have important publicity costs that force the recalcitrant

41 WT/DS160/R (June 15, 2000).

42 Ibid., para. 8.1. "WTO Says Ecuador can Seek Retaliation Against EU for Bananas" Inside U.S. Trade (March 24, 2000). 
government to devise a solution.

As mentioned, deep controversy persists over the meaning of conformity. The EC made this clear in the Hormones case, where it refused to withdraw the infringing measures. Its initial line of defence was to argue that it was entitled to do anything that was not inconsistent with the recommendation during the period of reasonable implementation. In its estimation, this consisted of conducting risk assessments on hormone usage in meat. When the period came to an end, it adopted an uncompromising attitude which was met with the equally uncompromising attitude of its principal opponent, the United States. Given the acrimony the parties could not subsequently decide on mutually acceptable compensation and retaliation was eventually authorized.

The question of conformity appears to turn on the definition accorded to that term. On the one hand, conformity does not necessarily imply identity with the object being conformed to. A margin divergence appears acceptable, as the EC argued in the Hormones case. ${ }^{45}$ On the other a teleologic interpretation would indicate that withdrawal was the only conforming act possible given the "reasonable period of time" within which to do so. In the Hormones case, the 15-month period established by the arbitrator must have appeared to the EC too short a time to complete the relevant risk assessments - particularly when the EC initially requested a much longer period to do so - and therefore for its plan to be non-conforming. Similarly in Australia - Salmon Australia protested that a brief period of compliance would not allow it enough time to devise replacement measures.

The lesson to be drawn from conformity appears then to be one of conformity in context. Where the parties agree, then conformity is achieved. Where they do not and where nonconformity can be verified independently, retaliatory suspension is permissible. This leaves an uneven quality to WTO law, one that is very much a product of competition between normativity and sovereignty. The idea of a conformity in context is surveyed in the following section.

\section{The WTO Agreement and the Context of Conformity}

Having examined remedies, we are left to review what they achieve. The language of the DSU continues to reflect the tension between distributive and corrective justice. In DSU Art. 3, for 
instance, the aim of the system is variously described as leading to "prompt settlement of situations", to "a satisfactory settlement of the matter" and to "a solution mutually acceptable to the parties to a dispute and consistent with the covered agreements." At the same time, DSU Art. 3 also refers to the dispute settlement system as constituting "a central element in providing security and predictability to the multilateral trading system." There is evident distinction between settlement, which implies agreement at intermediate points that may be convenient to the parties, and "security and predictability", which implies an a principled-driven adherence to precedent that goes beyond the parties and provides guidance to a wider audience in the form of "the multilateral trading system". On this critical issue Amelia Porjes has observed that "[t]he DSU incorporates both settlement values and rule-compliance values at each step of the process." 46

It is important to appreciate that the diverse obligations now embodied under the WTO Agreement there can be no one single remedy. Rather, what is suggested here is remedies across a spectrum of conformity, as seen below:

To begin with, there are remedies where the bright line is apparent from the very wording of the treaty text. An example is the wording of GATT Art. II:1(b) which provides that good from other WTO members shall be "exempt from ordinary customs duties in excess of those set forth and provided in [the relevant member's schedule of concessions]." Conceivably, any amount of excess would be caught by this requirement, as identified in $E C$ - Computer Equipment. ${ }^{47}$ Another, somewhat more nuanced, example is contained in TRIPS Art. 50(6), which provides that:

... provisional measures taken on the basis of paragraphs 1 and 2 shall, upon request by the defendant, be revoked or otherwise cease to have effect, if the proceedings leading to a decision on the merits of the case are not initiated within a reasonable period, to be determined by the judicial authority ordering the measures where a Member's law so permits or, in the absence of such a determination, not to exceed 20 working days or 31 calendar days, whichever is the longer.

The requirement here is specific. It treats provisional measures in domestic intellectual property 
proceedings as revocable where 1) there is a request by the defendant, 2) there is no domestic rule, and 3 ) a time period ( 20 days or 31 calendar days). Moreover, the term "a reasonable period" could presumably be the basis for a WTO challenge if in some instance the standard provided in national legislation were somehow unreasonable. Again, that would most likely be determined by measuring national law against the WTO Agreement. TRIPS Art. 50(6) thus provides a definite standard against which domestic behaviour can be measured, and a means to resolve the matter where it cannot.

This end of the spectrum of the WTO is one where there is a high degree of what Thomas Franck refers to as normative clarity. ${ }^{48}$ It is relatively easy to conform because the standards are clear and presumably reflect the intent of the negotiators. There is, in other words, a high degree of consensus over what the desired conformity should look like. A WTO member will change its law to provide for revocation within a reasonable time or will have the default of 20 days or 31 calendar days apply.

Many other WTO obligations are, however, not so clear and therefore evade the relatively straightforward conformity seen above. For the most part, even the most basic of WTO obligations involve some measure of interpretation and some degree of contextualization among the parties, and therefore suggests that a varying degree of compliance will be achieved from case to case. Many obligations will be close to the normative compliance range, but not invariably so, and we can expect that, over time, some considerable variation will occur as WTO members apply their own gloss to the circumstances or point to previously imperfect compliance in order to justify their less-than-perfect adherence.

Further along the spectrum of compliance is an intermediate zone where conformity is characterized by negotiation. Here, the rules are still less immediately clear and the country subject has greater discretion in its implementation. A useful example is that of the so-called "environmental" exception under GATT Art. XX(g) at issue in U.S. - Shrimp. ${ }^{49}$ In that case, the law's application was found to have violated the WTO Agreement and the implementation

\footnotetext{
48 T. Franck, The Power of Legitimacy AmOng Nations (1991).
} 
question then became whether the United States was obliged to negotiate with its trading partners in redesigning the law's application. On DSU Art. 21.5 review the reconvened panel said that the United States did, but that it could maintain the original measure provisionally while negotiations continued. The panel also specified that measure could remain pending a final determination. ${ }^{50}$ On appeal Malaysia, as applicant in the case, made the argument that the reconvened panel's determination would have the effect of allowing a measure found to be WTOinconsistent to remain in place. The implicit position of the Appellate Body was that this is a "characteristic of all the exceptions", and to some extent, a reasonable attribute of sovereignty. ${ }^{51}$ Where the line would be drawn from case-to-case would depend in precise terms on the context. The important point here is that the defendant has an obligation to negotiate, and that the WTO Agreement, while providing a threshold of compliance, dictates that conformity remains a multilateralized affair. Indeed, implementation in the Shrimp case illustrates that compliance will probably go far beyond the original complainants to involve all those with an interest in supplying the relevant market. ${ }^{52}$

The final category, sitting at the far end of the proposed spectrum of conformity, is that of unilateral behaviour in fields of traditional sovereign concern such as national security or health and human safety. Here governments enjoy considerable leeway in what they legislate and its impact on trading partners. In the E.C. - Measures Affecting Asbestos and Asbestos-Containing Products ${ }^{53}$, for instance, the measure at issue was an outright prohibition on the manufacture, processing, sale, import, placing on the domestic market and transfer of all varieties of asbestos fibre. The French government's ban was upheld by the Appellate Body on the ground that imports of asbestos-containing products were not "like" ordinary domestic products due to the inherent danger they posed. Because of this central distinction, the Appellate Body did not carefully examine claims associated with France's obligations under the SPS Agreement, such as the requirement of "minimizing negative trade effects" set out in SPS Art. 5.4 or of ensuring that "such

\footnotetext{
50

51

52

${ }^{53}$ WT/DS135/AB/R (March 12, 2001).
} 
measures are not more trade-restrictive than required to achieve their appropriate level of sanitary or phytosanitary protection" in SPS Art. 5.6. Asbestos was likely something of an atypical case given the finding on likeness. Nevertheless, the text of the SPS Agreement suggests that so

long as threshold standards are met the application of a higher standard than internationally acceptable could be contemplated. The Asbestos case demonstrated that indeed the application of a higher standard than internationally acceptable could be contemplated provided SPS standards are otherwise met. At the same time, the Appellate Body in that instance seemed to play down the importance of

The result in Asbestos suggests the other extreme to the spectrum of compliance. At this point unilateral determination of protection, and consequently a unilateral point of conformity, is appropriate and conceivable. It is an assertion of the sovereignty principle.

\section{VI. $\underline{\text { Conclusion }}$}

WTO dispute settlement has been, for the most part, facially successful and it does not appear that the application of remedies would change the compliance rate tremendously. WTO remedies are more of a threat, set at the end of a multi-year process that itself has a substantial value in settling cases. What I suggest will make more sense is to understand WTO remedies in a contextualized manner, to identify the nature of the underlying obligation, the relationship of the parties, and the treaty text. In respect of each element we can ask the following questions: Is the obligation concessionary or absolute

Given the fact that concerns of deference, legitimacy and expertise are amplified on the international stage, it is not surprising that declaratory relief is a popular choice in several institutions of international law or that a bare recommendation of conformity is the principal remedy of the WTO system. An indication by WTO dispute settlement panels or the Appellate Body that a country must bring itself "into conformity" is sufficiently directive, yet ambiguous enough, to require a country to do something without raising issues of calculation, supervision or sovereignty. Instead, these are progressively defined by the wrongdoer and its trading partners, who are left to articulate what the shape of the ultimate remedy will be. Dispute settlement is a passive agent that the parties can turn to where they are at an impasse to pronounce on 
consistency. Through this process of remand, of return and reassessment, that an acceptable solution is eventually reached.

This preliminary conclusion - of a dispute settler of a passive nature and the involvement of the parties in fashioning their own relief - leads to some observations. Perhaps the most important is the diminished regard for strict legality. WTO remedies are meant to induce compliance with the WTO Agreement, but they do so in an indirect way that has limited coercive attributes. The result is an assembly of approximations around a norm rather than any uniform adherence to a single rule. To the extent that this troubling, it is useful to recall approximation being the normal experience in human affairs, as illustrated in the number of times a day that someone runs a red light. Another observation is the difficulty in such a system of policing specific injury, that is, instances under the treaty where circumstances are definite enough to identify harm and remedy it. Such situations do exist under the WTO Agreement, notably in the context of safeguards, subsidies, anti-dumping and customs valuation, but their breaches only provide, at best, proxies around which to organize remedial thinking. This leads to the conclusion that in the circumstances it is hard to come to any meaningful sense that justice is done. This, in turn, that calls for more corrective justice in the WTO may not improve remedies.

perhaps even more importantly, to clarify the obligations at hand so as to identify when violations arise.

Part of the difficulty with WTO determinations involves their lack of specificity. Apart from recommendations, rulings, suggestions and "concluding remarks", panels and the Appellate Body have used a number of methods to condition the remedy. In United States - Shrimp, for instance, the Appellate Body made the following statement clarifying what had not been decided. In Guatemala - Cement the Appellate Body found that Mexico's complaint about a Guatemalan antidumping measure was not properly before the panel because Guatemala had not made a definitive anti-dumping determination necessary to trigger dispute settlement under Art. 11.3 of 
the Anti-dumping Agreement. The Appellate Body observed that Mexico was free to bring proceedings when the definitive determination was made, an eventuality that, in fact, later came to pass. In Turkey - Restrictions on Imports of Textiles and Clothing Products, a case which involved Turkey's imposition of quantitative restrictions on imports of Indian textiles in preparation for a customs union with the EC, the Appellate Body found that the Turkish measures were WTOinconsistent but also observed the "reasonable alternative" of a system of certificates of origin.

In addition to specific remedies, it is evident that retaliation could be made more specific still through creative targeting of obligations depending on the particulars of the trade involved, which may be small and composed of few products. In such cases the country proposing retaliation would presumably have a stronger case for cross-sectoral retaliation under DSU Art. 22.2. In Brazil - Aircraft, for instance, Canada has contemplated revoking sunset reviews for antidumping duties on Brazilian goods and the suspension of discretionary licencing for Brazilian goods under the Agreement on Import Licencing.

Substantively, however, the two systems differed, and substantially so. While collective security was premised on the idea of collective action for the restoration of international peace and security, GATT Art. XXIII had three functions: 1) to establish the requirement to consult, 2) to obtain compliance, and 3) to ensure continued reciprocity and the balance of concessions. It is not entirely clear that these were met. For one, it was not entirely clear what compliance meant. For another, the obligation to ensure continued reciprocity and the balance of concessions was vague. By nature the balance of concessions was constantly shifting as countries traded with each other, as products came and went, as technology and government policies changed, and as exchange rates varied.

the remedies that evolvedLeft the flexibility to take unilateral or action

Several commentators have recently expressed the view that GATT was largely "a 
package of bilateral equilibria" and that the WTO Agreement has matured into a "single package" agreement where obligations are absolute and the power of remedies is stronger. In the present view, no such easy conclusion can be reached. Instead, it seems more accurate to say that remedies under GATT and the WTO Agreement are a blend of settlement and compliance values, reflecting the nature of the obligations, the power of the parties, and the wording of the treaty text. view runs counter to that of several recent commentators who regard GATT as a collection of reciprocal exchanges between negotiating partners, principally to contend that the new WTO is more sanctions-oriented in its approach, but no such conclusion should be attempted. While it may be moreso, the characterization of GATT as It requires elaboration. ${ }^{54}$ First, it should be recalled that GATT was styled "the General Agreement". This distinguished it from both the U.S. Reciprocal Trade Agreements Act of $1934^{55}$ on which it was based and on other prewar agreements that were selective in their membership. The reciprocity exchanged in GATT was only to be a foundation for greater multilateralism. Second, nowhere was this multilateralism more evident than in the obligations of GATT Art. I, the Most-Favoured-Nation Clause, which required that all benefits "be extended unconditionally" to all other comers. This meant, for instance, that if the United States gave France (later the European Community, or EC) a favourable tariff rate on wine, it was bound to do so for all other GATT members regardless of what they gave it. That nonconditionality was a powerful stimulus to winegrowers outside France, in South Africa, or Chile, or Australia, to expand production and take advantage of the new market opportunities. The synergies were significant and went well beyond any original bilateral balance of concessions. ${ }^{56}$ Third, the nature of obligations were not all calibrated or concessionary. For example, GATT Art. X set out fairness and due process requirements that could not possibly be linked to any specific amount of trade; thus, Art. $\mathrm{X}$ does not provide more procedural fairness because a country exports more. In several respects, then, GATT embodied multilateral values from the outset. In this respect, GATT very definitely meant to create a "public

54

55

56 It is also extremely significant that MFN obligation was one of the few in the original GATT that was not subject to grandparenting. 
good" in the trading system, something that was of common benefit to all participants regardless of the specific concessions each one made

Like collective security, GATT operated as a communal expression of disapproval. Like collective security, GATT preferred third-party dispute settlement, negotiation, and, where all else failed, pre-approved proportionate retaliation. These were important developments. It is, perhaps, not surprising that the general experience of the two systems was similar. Most disputes were solved informally and in an amicable way.

Several recent decisions have raised the issue whether there is an obligation to negotiate over domestic standards that otherwise comply with WTO requirements? The Shrimp decision in particular brought this issue up and as well as the issue of how long one could maintain a WTOinconsistent measure. In the environmental realm this appears important, given that norms are still evolving, the exact WTO requirements are vague, and that are controversial. This is not true for all WTO disciplines. In the domain of human health the Asbestos case demonstrated that a purely domestic standard might be non-negotiable and still perfectly WTO-consistent. At the other end of the sovereignty spectrum are positive WTO obligations, such as are found in the TRIPS Agreement, where the content of compliance is fulfilled only by adherence to specific multilaterally agreed rules. There, inconsistent domestic standards have no role at all. Thus, the specific content of WTO compliance varies from discipline to discipline. No single rule can be posited for all.

What appears to be more problematic is that of a "practice". A practice followed in an anti-dumping methodology has subsequently been continued.

Examples abound: an import ban on agricultural products suddenly gets transformed into a phytosanitary measure; a country's anti-dumping methodology is condemned but later saved as a WTO-consistent "practice"; a market access agreement ending a WTO dispute covers only one 
country; an WTO-inconsistent quantitative restriction is removed and precipitously replaced by safeguard action.

It could be argued in many of these cases that the action following is WTO-consistent and that this is all that matters, but such would appear at times to skirt the edges of the system and to violate the spirit of trade liberalization in which the WTO was drafted. The behaviour may be an important cause of increasing frustration with the system in some quarters, particularly among developing countries. They enter dispute settlement with the expectation of relief only to find that the expense and effort is rewarded with further delays to meaningful market access. If dispute settlement is little more than a procedural formality devoid of benefit for the complainants involved, there will be increasing skepticism about the advantages of the system.

The contradiction, that while we retaliate based on "nullification or impairment" of the complainant's market access, the real aim of the system is to induce the defendant's compliance. This disconnect is troublesome. Reconceive of this remedial structure. In essence, that it should not be based on harm caused but on the benefit accrued.

The remedial experience of the WTO to date has been akin to that of GATT.

GATT dispute settlement therefore had much in common with the public law model seen above. Why did it not meet the coordinate obligation of reparation? As we have seen, material repair plays a diminished role in any system of international law. There was more stress on observance of the law than reparation of the injury. It might be supposed that the actors countries - were large enough that most material injury did not matter to them, but no clear evidence exists in the negotiating record that this was in fact the case. There were also other reasons. These were the familiar ones of supervision, calculation, and sovereignty. GATT panels were mindful of compromising their position, of engaging in the difficult task of calculation, and of infringing sovereignty in each of these tasks as they set out to craft relief.

Recommendations in a few GATT cases generated debate by going beyond simple withdrawal of the legal measure and requiring removal of the measure's effect. The nine Tokyo Round codes, in particular, changed the nature of obligations that were considered part of GATT. Whereas GATT focused traditionally on substantive requirements - on Most Favoured Nation 
status, National Treatment and the prohibition on quantitative restrictions - the Tokyo Round codes emphasized procedural rules for government behaviour in fields of anti-dumping, subsidies, technical barriers, customs valuation and the like. The difference between the old and new obligations was dimensional. Denial of the substantive obligations of GATT meant denial of market access: a violation of GATT Art. I's MFN obligation meant your country's goods did not have the same opportunities in a foreign market as your competitors. However, denial of the procedural obligations in the side codes was a double denial: a violation of GATT Art. VI and the Subsidies Agreement meant your country's goods did not enjoy the same procedural and market access conditions as their competitors. Moreover, the means of remedying this new "double" injury was unclear. Did you insist solely on a new procedure without any accounting for interim injury? This smacked of formalism and was to be a tension in GATT.

For instance, in the 1985 panel report New Zealand - Imports of Electrical Transformers from Finland ${ }^{57}$, the panel recommended reimbursement of anti-dumping duties. Five other GATT panels or panels convened under the Tokyo Round Anti-dumping or Subsidy Codes made like recommendations, calling for the return of duties inconsistently levied. There were also a few GATT cases dealing with government procurement involving denial of the opportunity to bid. Practice, however, betrayed a pattern of reluctance. The United States, as defendant in four of the six GATT "specific remedy" cases, never reimbursed the duties. It is not clear whether the other countries involved followed suit.

GATT's specific remedies in these instances satisfied the penchant for certainty, but they also restricted the room to negotiate and, as will be seen, amplified difficulties of compliance through evasion, recrimination, and the loss of institutional prestige. Tension was evident between the distributive and corrective aspects of GATT remedies. In the few instances where specificity was featured, such remedies appear to have been more a series of one-off reactions to particular circumstances than a group of decisions based on a coherent theory of relief. The record elicited negative reactions from the Contracting Parties and spurred later efforts to restrict GATT remedies. 
Much has already been written about WTO remedies elsewhere. This article does not attempt a wholesale review of the remedies granted in each case. Instead, it focuses on what outcomes have been achieved with the existing regime of remedies and offers some observations related to the points made above.

understood in light of the previous discussion by surveying some history. The exchange of tariff concessions that led to the creation of GATT in October 1947 was sponsored by the U.N. Economic and Social Council and there is at least some evidence that GATT, and the stillborn ITO, were supposed to be a transposition of the U.N.'s concept of collective security into the economic realm. ${ }^{58}$ This is evident from the negotiating record. It is also evident from the wording of GATT Art. XXIII:2, which states:

If the CONTRACTING PARTIES consider that the circumstances are serious enough to justify such action, they may authorize a contracting party or parties to suspend the application to any other contracting party or parties of such concessions or other obligations under this Agreement as they determine to be appropriate in the circumstances.

The language employed in Art. XXIII:2 demonstrates that multilateral action against wrongdoers was clearly contemplated and, moreover, that it could have been independent of the level of concessions, as evidenced by use of the term "appropriate". Nevertheless, retaliatory action under GATT evolved in very deliberate way towards authorization of unilateral action against the wrongdoer by a complaining state, ostensibly to ensure continued reciprocity and maintenance of the balance of concessions.

It is clear, however, that even the original GATT involved much more than bilateral concessions but also included an entirely new set of administrative rules, such as openness, transparency, and accountability, that were meant to a more secure and predictable world trading system regardless of the level of concessions granted. In so doing, GATT was a hybrid system that built on the utility of unconditionally multilateralizing a series of bilateral exchanges. 
GATT's remedies were, and under the WTO Agreement remain:

1. settlement

2. withdrawal of the impugned measure

3. compensation in the form of tariff concessions

4. retaliatory suspension.

\section{Remedies under the WTO Agreement}

Other commentators have taken different views. In 1999 Joost Pauwelyn described the DSU's function of "rules as rules".

The foregoing views belie the differences of opinion. It is wise to examine this more closely. Given the ambiguity of the DSU and the inconclusive pronouncements of the Appellate Body and commentators, it is useful to examine the pattern of practice further. There is clearly a commitment to legal adherence, but whether there is one to substantive inherence and the rules are rules approach is more problematic. GATT itself evolved from a pattern of settlement to rule compliance. In this respect, a key development was the Agreed Description of 1988, where it was made clear that settlements were to be "consistent with the covered agreements". It would seem that this was a clear step towards the "rules as rules" approach. Yet one also has to examine practice and here the result is less evidently clear.

The leading remedies are a settlement consistent with the covered agreements, followed by compensation, and ultimately retaliation. These are not alternatives. Instead, they are expressed in a descending hierarchy, with retaliation clearly identified as a "last resort". What confirms this are the numbers. The majority of disputes begun at consultations do settle. However, in light of uneven reporting it is not clear if they are always "consistent with the covered agreements". Certainly this would appear not to be the case at the present time. There are several well-known instances of inconsistent WTO settlements. This is a critical question in urgent need of further research. Practice, therefore, as contemplated under the Vienna Convention and the ICJ Statute suggests slippage and a strict rule-based approach is, perhaps, too catgeoric. There is a need to examine the cases further. 
Likewise in .... .

Much has been made by commentators recently about how the early GATT being fundamentally a "package of bilateral equilibria" and that the remedy of withdrawal really sought to re-establish the balance of concessions

This realization is important because several commentators have posited the view that the WTO Agreement is a significant departure from the bilateralism of the old GATT towards the sanction-driven absolutism of a "single package". In this new orientation they believe that coercive remedies are, or can be, much more important. This view is only partly correct. GATT, like the WTO Agreement after it, embodied a blend of both settlement and compliance values. Consequently, the question of adherence is considerably more complicated than a single look at the cases suggests and depends to a great extent upon the specific wording of the treaty, the substantive nature of the obligations assumed, and the relationship between the parties to a dispute. There is substantial evidence of non-compliance beneath the surface of apparently compliant behaviour. This calls for a more sophisticated assessment of WTO compliance than has been offered to date. 
The principal point to be gleaned from the examination of public law is that it had the same characteristics: a need for ambiguity to accommodate state interests. domestic law is that transposition of the foregoing ideas into international law is challenging but ultimately unnecessary because they have ready equivalents there. A central contention of this article is that the same general remedial structure developed above - of deference, passive decisionmaking, and a preference for declaratory relief - are repeated, with appropriate modifications, in international law. They are the key to understanding the form that remedies take today under the WTO Agreement.

Certainly This opinion has been repeated, and to some extent amplified, in other instances, but this simple phrasing left many questions unanswered: what was "reparation in an adequate form"? The facts of Chorzów Factory help to illustrate some answers. The case arose from the expropriation of a match-making factory in Poland owned by a German national. The new Polish Government acted against the factory in 1921 and the Weimar Republic took its national's claim to the Court in 1924.

Subsequent to Chórzow the PCIJ and its successor ICJ

The foregoing principles have been enshrined in the Draft Articles on State Responsibility, the first provision of which now reads that "[e]very internationally wrongful act of a State entails the international responsibility of that State." The work of the International Law Commission is also very important for the definition of remedies in international law. Since 1956 the Commission has studied the question in the course of its work on the Draft Articles on State Responsibility. The work has been through numerous drafts under the direction of several rapporteurs. The present Draft, completed under the direction of the current Rapporteur, James Crawford, was adopted by the Commission in August 2001.

In particular the Commission's work now makes clear that the State responsible for the internationally wrongful act is under an obligation: (a) to cease that act, if it is continuing; (b) to 
offer appropriate assurance and guarantees of non-repetition, if circumstances so require. This double obligation of cessation and reparation

Article 31, moreover, makes clear the duty to repair, as follows:

1. The responsible State is under an obligation to make full reparation for the injury caused by the internationally wrongful act.

2. Injury includes any damage, whether material or moral, caused by the internationally wrongful act of a State.

Setting cessation apart from reparation deals with two different aspects. The first is the breach of the primary obligation, the one which is owed. The second deals with the consequences of the breach. Under WTO law, it is evident that the cessation is the primary concern. Why is this so? The Rapporteur on State Responsibility has observed that cessation assumes greater importance in international, as opposed to domestic, law because it lacks a coercive mechanism. Where states cannot be compelled to take positive measures, they should at least be obliged to observe the bare rule of law. Cessation therefore stresses "not only the interest of the injured State or States but also the interests of the international community in the preservation of, and reliance upon, the rule of law." It is stresses of the law, as opposed to the obligations that flow from it. Cessation is the foundation of a system of pure law, whereas in domestic law, where coercion is present, it may be theorized that the obligations are stressed because there is a means of enforcing them.

Reparation, on the other hand, deals with the consequences of injury and, to this extent, is seen to protect a secondary, and in some senses, a lesser, right in international law. Several distinctions between cessation and reparation require examination. First, as the Draft Articles' make clear, cessation and reparation are distinct and address different interests. Cessation targets "the wrongful conduct per se, irrespective of its consequences." That distinguishes cessation from consequent injury and is an important factor in coming to the conclusion, as shall be seen under GATT, that cessation of the wrongful act and a return to compliance may be achieved without any demonstrable injury. The logic of declarative relief, which identifies inconsistency and leaves it to the parties to decide on the appropriate repair, is close, if not 
identical, to this logic. Second, the obligation of cessation is absolute, whereas the obligation to repair is, as seen, more evidently conditioned. Classically, the right to seek reparation belongs to the injured state alone, which must decide whether to pursue or forego it. Third, cessation is prospective. It means to cease the illegal activity henceforth into the future. Reparation, on the other hand, is normally retrospective, being focused on injury that has taken place. Only exceptionally will it be prospective. In temporal perspective, then, cessation and reparation converge to occupy the entire temporal spectrum in a concurrent, but rarely overlapping, fashion.

With respect to reparation more particularly, the Draft Articles define it as encompassing several subordinate remedies: restitution in kind, compensation, satisfaction, or assurances and guarantees of non-repetition. They are available single or in combination, but together can amount to no more than one recovery. Restitution, or more accurately restitution in kind, is the form of reparation which would eliminate all the legal and material consequences of the injury. In this sense it offers the most complete degree of repair. The return of looted art or restitution of expropriated property is restitution in kind. Compensation is available wherever injury is not made whole by restitution. In this sense it is a clear substitute, covering "any economically assessable damage sustained". Practical problems with providing restitution in kind means that compensation is in fact "the main and central remedy resorted to following an internationally wrongful act." Satisfaction in international law covers moral damage to a state, that is, injury to its intangible dignitary interest. Due to the abstract nature of the interest they cover they are not of any more interest here. Finally, assurances and guarantees of non-repetition provide the injured state with security in the knowledge that the wrongful act will not be repeated.. The remedy is clearly future oriented and has a preventitive aspect. It is of particular interest in the GATT/WTO context because the most usual remedy in response to a WTO violation is the withdrawal or amendment of national legislation. The Sixth Rapporteur on State Responsibility, Arangio-Ruiz, gave the example of a French demand in 1919 for abrogation of Art. 61(2) of the original Weimar Constitution which, France claimed, violated the Versailles Treaty by providing for the participation of Austrian delegates in the German Reichsrat (the Weimar Parliament). Following France's protest, the provision was annulled by Germany. Like forms of remedy have been 
known in the WTO era. In Canada - Certain Measures Concerning Periodicals, for instance, Canada eventually settled the dispute by withdrawing its legislation and allowing for phased entrance of outside in advertising services. In the EC - Bananas the European Community reconfigured its banana import quota through a change in regulation to allow for entry on a firstcome, first-serve basis. In U.S. - Conventional and Reformulated Gasoline the United States modified regulations to allow for equal treatment of foreign and domestic refiners.

What each of the foregoing examples demonstrates in a very real way in which the change is legal restitutio, a legal repair that has little to do with the actual conditions of market access. It seeks to change the conditions on the ground regardless of what actual market conditions may prevail.

In considering the form of remedies, it is vitally important to keep in mind their purpose. They are undertaken "in order to induce [the wrongdoing State] to comply with its obligations." Thus, remedies are oriented at encouraging the defendant to conform. They are less immediately concerned with the obligation to correct. In addition, they can only be resorted to after a number of important conditions are met, including fulfillment of the obligation to negotiate and pursue dispute settlement, proportionality, and the absolute prohibition on countermeasures that cause "extreme economic or political coercion", derogations from basic human rights, or conduct in violation of preremptory norms of public international law. These qualifications almost certainly ensure that remedies will be less immediately effective than the wrongful act, which must rarely meet such conditions. In this respect, the remedial "deficit" is already evident.

\section{VI. $\underline{\text { Conclusion }}$}

What observations can be usefully drawn from the above review? Perhaps the most important is that GATT and WTO remediation emanate from a tradition of public and international law that does not concern itself with individual injury.

The traditional form of GATT changed radically as a result of the Tokyo Round. What were introduced were definite rules.

How are all of the above to be classified? We might also think of some traditional GATT/WTO concepts more flexibly. For instance, the requirement of "equivalent" retaliation under 
DSU Art. 22.4 has been criticized by some commentators, who believe that arbitrators passing judgment have been too narrow in their interpretation of equivalence. Perhaps it is time to seriously consider broader notions of equivalent retaliation such as some of the elusive trade effect that this might have on other countries, or the readily observable fact that some countries find it worthwhile to continue violating WTO disciplines even after a determination has been made against them, thereby suggesting that there is an uncaptured "value" that determinations of nullification or impairment do not reflect. Perhaps it is .... Perhaps too it is.

One note of caution would be the observation that WTO dispute settlement is not, in the main, about the hard values of litigation, quantification and an eye-for-an-eye retaliation, but rather that the system function as a process. As John Jackson observed in 1969, "it may be that there is greater value in the processes than in all of the rules combined." Certainly the evidence of state practice lends credence to this view. WTO members would appear to settle their disputes both before and after formal dispute settlement proceedings on the basis of a "guilt" that, it could be said, is almost independent of the quantum of retaliation. The outstanding difference remains in the public (or at least official) eye and is moved along, a sorry reminder of an impasse. At some point countries are compelled to settle the matter, just as the United States did with the Netherlands in 1959 and as the European Community did with Ecuador in 2000. The bare economics of the settlement do not make sense; only the diplomatic value of broader welfare do. What are the alternatives? This is critical in the subsidies area where it would appear that discipline has broken down and the weaknesses of the system have been exposed. In this respect the Australia - Leather is an important but troublesome decision. There the panel $f$

What are some solutions? To begin with, it is important to note the wording of DSU Art. 22.4. It says:

The level of suspension of concessions or other obligations authorized by the DSB shall be equivalent to the level of nullification or impairment.

The stress here is on equivalence between the level of suspension and the level of nullification or impairment. ${ }^{59}$ This emphasis is cause for pause, since the wording clearly focuses on the

\footnotetext{
59 In this regard it is interesting to note that the applicable standard in general international law is more permissive. Article 51 of the Draft Articles on State Responsibility only requires that
} 
complainant's injury ("nullification or impairment"), not the defendant's benefit in undertaking the WTO-inconsistent act. Economic theory would posit that if the defendant is benefiting from the violation more than it must in nullification or impairment, then there is an incentive to violate. Given this, a number of commentators have suggested that WTO remedies assume more of an afflictive character. If they were accepted such suggestions would lead to the abandonment of a strict "equivalence". They would be problematic in the sense that the government's legitimate exercise of its sovereign power to govern would be compromised in the subjection to penalty, which is, in any event, formally unknown in international law.

What seems more acceptable to both the intent of the drafters and the treaty text is to reconceive the "equivalence" standard to better account for all of the nullification or impairment that a WTO-inconsistent act causes. This may be appear to be a slight distinction, but is is an important one given the need for legitimacy in discussing interpretative changes. As matters now stand there is a significant discount to the injury that a WTO violation causes. To begin with, the WTO has no system of interim relief, meaning that there is an incentive to drag proceedings out over time. ${ }^{60}$ Litigation has revealed that WTO members are fiercely protective of their "reasonable period of time" for implementation. They routinely make inflated claims before arbitrators under DSU Art. 21.3(c) proceedings and rarely implement until the last possible moment, if not beyond. This behaviour suggests that there is a benefit to be had for the wrongdoer and a corresponding injury to the complainant from delaying compliance that is not as yet internalized in any strict standard "equivalent ... nullification or impairment." The evidence suggests that in some cases this interim injury can be substantial. In Brazil - Aircraft the Brazilian aircraft manufacturer, Embraer, on whose behalf defence was maintained by the Brazilian government, put an extra effort into selling its subsidized passenger jets during the RPT. It then prolonged the dispute by seeking an unprecedented appeal and repeated instances of compliance-related proceedings. As

"countermeasures must be commensurate with the injury suffered, taking into account the gravity of the internationally wrongful act and the rights in question." [emphasis added]

60 Interim measures are problematic in international law. This is also reflected in Art. 52(3)(b) of the Draft Articles on State Responsibility, which provides that "[c]ountermeasures may not be taken, and if already taken must be suspended without undue delay if ... (b) The dispute is pending before a court or tribunal which has the authority to make decisions binding on the parties." 
of the time of this writing, the violation effectively continues.

A second consideration that must inevitably add to the discount inherent in equivalence are certain obligations that may not, as a matter of international law, be affected by WTO countermeasures. These are profound. The Draft Articles indicate, for instance, that permissible countermeasures shall not affect the obligation to refrain from the use of military force under the U.N. Charter, from obligations to protect fundamental human rights or other obligations of a humanitarian character prohibiting reprisals, or preremptory norms of general international law. It is perhaps difficult to conceive of when such obligations would be violated, but as the realm of "fundamental human rights" or other obligations of a humanitarian character grow in nature and extent this could potentially extend far. Take, for example, the invocation of a patent right to save lives. These are substantial, and wrongdoers do not always labour under them as well, suggesting, again, that there are unenumerated benefits to noncompliance that a strict "equivalence" standard does not account for.

We have already seen theoretic restrictions that may not be derogated from. A third observation is with respect to the practical restrictions that are placed on proposals for retaliation under the WTO Agreement. The real and often conflicting obligations encountered may face for retaliation and suggests that retaliation may be more difficult and, consequently, poses little material threat at all. This was well-illustrated in Ecuador's proposed retaliation against the European Community in EC - Bananas. There, Ecuador completed a preliminary list of $\$ 210$ million worth of goods that the unified EC banana tariff was said to "nullify or impair". In submitting its list of proposed retaliation, however, Ecuador made the request to implement cross-sectoral retaliation given that it did not import enough in the affected field (agriculture) from the Community to make a difference and given that most of its imports were in the Community were in the form of capital goods such as machinery and spare parts, the absence of which would cause significant hardship for the Ecuadorian economy. In this connection it proposed to retaliate by suspending concessions in services and intellectual property.

The Ecuadorian proposal was novel, but what it could not foresee were the arbitrator's objections. The arbitrator noted that suspension of services' commitments would cause undue 
hardship, particularly in suspension of the mode of commercial presence where certain established EC subsidiaries in Ecuador would have to close and in abrogation of intellectual property rights. Not only would both proposals disrupt individual businesses, but in the case of intellectual property commitments would also have to obtain permission of the relevant international organization in the field, presumably WIPO. Finally, the panel noted that when Ecuador did decide to retaliate, it was obliged to ensure that the services or intellectual property consumed in violation was confined to the Ecuadorian market "in order to ensure the least disruption to world trade patterns." These restrictions were presumably enough to make Ecuador, which was then undergoing the worst economic crisis of a century, postpone the idea of retaliation altogether. The Bananas case was settled in June 2000 with the introduction of a firstcome, first-serve tariff by the Community and without Ecuador having retaliated at all. Nevertheless, the case was an excellent illustration of the practical problems of retaliation, particularly for developing countries which now compose 80 percent of the WTO's membership. ${ }^{61}$ Other results suggest that meaningful retaliation remains problematic even between developed countries where trade is already limited. In the FSC decision, for instance, a dispute involving EC dispute of an American tax measure, the EC has publicly questioned the wisdom of retaliating in the full amount of retaliation, worth potentially some $\$ 4$ billion annually. ${ }^{62}$

The reality that suspension of intellectual property commitments are free, that is, their abeyance would allow national producers in the injured country a cost advantage, since they would be able to use the intellectual property without paying for it. Tariff hikes would make manufacturing more expensive, although it might provide a temporary stimulus for domestic manufacturers to step in the breach and pick up the slack.

61 An additional problem with the suspension of intellectual property commitments would be the potential to encourage a "cult of illegality" after retaliation had ended, for instance, by encouraging the creation of an industry that would be forced underground (i.e. bottlegging CDs) once the suspension finished. The Draft Articles address this scenario, mandating in Art. 49(3) that "[c]ountermeasures shall, as far as possible, be taken in such a way as to permit the resumption of performance of the obligations in question."

62 In the Canada-Brazil Aircraft dispute, for instance, Canada's authorization to retaliate against \$344-million per year of Brazilian imports has not been implemented due, in large part, to fears about the impact of such an important retaliation on Canada-Brazil trade, worth annually \$2.2billion annually. 
A way of redressing the inequality inherent in the current restricted interpretation of "equivalent" may be to pay attention to the term "appropriate" in DSU Art. XXIII:2, which suggests contextualizing the remedy in different cases, and to recall the purpose of countermeasures under the Draft Articles, which are clearly "to induce that State to comply with its obligations [in international law]". There are clearly opportunities to reinterpret "equivalence" in DSU Arts. 22.4 and 7 to account for the some of the "discounts" discussed above and derive retaliation that is more truly equivalent. Several commentators have concurred in suggesting that retaliatory suspension could be collectivized or that the WTO itself might take some greater remedial role.

The view I take here is that this is unnecessary at present. The idea that remedies should be tailored to effectively induce compliance could also suggest that "equivalent" should be accorded a different definition if, over time, authorized countermeasures do not induce compliance. Possible actions could include shifting retaliation, as is now proposed in the U.S.'s "carrousel" legislation, or graduated suspension whereby the equivalent amount is intermittently recalculated with progressively fewer "discounts". It might, for instance, be possible after a certain time to increase in order to take account of interim injury, or of direct injury, or amounts for procedural and substantive harm. ${ }^{63}$

The above measures suggest are made on substantive modification of equivalence itself. However, retaliatory suspension need not be procedurally uniform either. The reconvened panel in Australia - Leather observed that its decision suggested removal "in this case", implying that in another case the finding might be different, and indeed has been. Guidance could be taken from United States - Anti-dumping Duties on Gray Portland Cement and Cement Clinker from Mexico where the panel acknowledged that there might be situations where it's request to reimburse antidumping duties could be onerous, for example where the inconsistent measure had been in place for a long time and calculation was onerous. It is important to observe that the statement by the panel in Portland Cement was not exhaustive of what constituted "excessively onerous". Simply put, panels could begin to craft exceptions to equivalent suspension depending on how long the

63 Under current rules it would appear always possible for a country to request authorization to retaliate in a given amount, but choose to impose a lesser amount at the beginning, leaving itself the possibility of increasing the amount to the total later on. 
case had been ongoing, whether the injury was a one-off event or continued, whether a least developed country was involved, and whether third parties, private parties or past transactions would be unduly upset. In some cases they have already begun to do so in their consideration of certain types of relief.

Likewise, some thought could be given to the continuing failure to consider interim injury in WTO dispute settlement. There us no clear reason to deny relief other than what can be termed a latent fear of "liability in an indeterminate amount for an indeterminate time to an indeterminate class." If the amount of retaliation permissible "nullification or impairment"

conciliatory value of The preference for a declaration is understandable when In a like vein, Edwin Borchard stressed the declaration. A declaration was useful where clarification of rights and duties was required and where the parties were interested in preserving the relationship beyond litigation.

An ongoing example in the United States involves court-ordered reform of the system of Indian trust funds, established in 1887 to administer royalties derived from commercial activities on Indian lands. In 1994 the U.S. Congress ordered the Department of the Interior to clean the system up after evidence that billions of dollars had been lost over several decades. ${ }^{64}$ The Department has put three reorganization proposals before the Federal District Court, each of which has been rejected.

Nevertheless the task of reforming government is vague and involves judges in the dayto-day affairs of outside institutions, something they are ill-disposed or suited to handle. A range of judicial behaviour is witnessed. It is conditioned by the traditional place of judges in the state apparatus, parties' reasonable expectations of judicial discretion, and the existence of legislation setting out the direction in which the legislature believes judges should go. Notwithstanding their

${ }^{64}$ Sweeping Changes Ordered in Indian Trust System, THE NEW YORK TIMES, Fri., Nov. 16, 2001, at $\mathrm{A}$. 
potential liberty, judges tend to err on the side of caution. ${ }^{65}$

The complexity of modern society also worked to make the old model of strictly corrective justice obviously deficient. The ethos of correction had to be expanded if the remedy was really to correct the wrong. Because the relief, there was a kind of distancing that occurred between injury and remedy. Close correspondence could not be maintained or insisted upon. Thus, the passage of Lord Cairns' Act in England in 1858 allowed plaintiffs to pursue damages for wrongs that continued into the future. ${ }^{66}$

New realities, then, demanded new remedies in public law, one which the declaration was well-suited to and continues to be. It is not difficult to see how in this conception the greater social value might be attenuated and eventually lost. The strident emphasis on injury and repair, of individuals and specific things, meaning all the while ignoring the idea that not everything can be corrected. Only now are we coming to see these collective rights, and the damage that overconcentration upon them, creates. At the same time are we alive to the renewed appreciation for what values the material remedial deficit can be said to represent. Beyond curing the injury it may lead to a greater social harmony, at least in that no social resources are spent on this. The remedial deficit is a "cost", one which might be said to constitute the price of social harmony. They are the price of allowing sovereign governments the freedom to govern.

This led to what some might call a disturbing trend towards, at the outside, relief for no material injury at all, that is, a purely creation of the law. In the eyes of those seeking legitimacy it erodes the basis of the law, but establishes its primacy.

In this respect, WTO remedy and countermeasures are controversial. For some, they run roughshod over national sovereignty, for others, they are cumbersome and flawed. A deeper understanding is pressing need, not only for those interested in the WTO but for a broader audience. The ever-present question of the recourse available for the breach of an international

65 Kent Roach makes the point, noting that both in India and the United States judges have proceeded cautiously with intrusive remedies such as structural injunctions. Governments are given repeated opportunities to comply. Detailed structural injunctions are a last resort. See KENT ROACH, CONSTITUTIONAL REMEDIES IN CANADA 13-17 (1994).

66 The innovation under Lord Cairns' Act was to provide damages in lieu of an injunction. See Jolowicz, Damages in Equity: A Study of Lord Cairns' Act 34 CAMB. L.J. 224 (1975); Jaggard v. Sawyer, [1995] 3 ALL E.R. (C.A.). 
obligation has been made pressing since the end of the Cold War by the international community's definitive rededication to international law. The number of transnational courts and tribunals is on the rise and more mechanisms of multinational adjudication are being contemplated all the time. To be legitimate, each institution needs a system of remedies. Here the example of the WTO may be of broader utility.

It is important to define what is to be examined here since there are a variety of causes of action and legal remedies under the WTO Agreement. This article deals principally with remedies for a violation of the WTO given under Art. XXIII:2 and the DSU. It does not deal with remedies in non-violation or situation cases, nor "compensatory adjustments" under GATT Arts. XIX (safeguards) or XXVIII (renegotiation of tariff concessions). 